\title{
ASSESSMENT OF TILLAGE TRANSLOCATION AND TILLAGE EROSION ON LOESS SLOPE BY CONTOUR MOULDBOARD TILLAGE
}

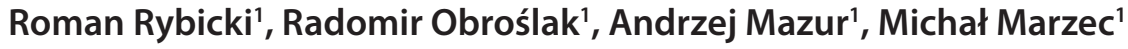 \\ 1 Department of Environmental Engineering and Geodesy, University of Life Sciences in Lublin, Leszczyńskiego \\ 7 Str., 20-069 Lublin, Poland, e-mail: roman.rybicki@up.lublin.pl, radomir.obroslak@up.lublin.pl, amazur70@ \\ op.pl, michal.marzec@up.lublin.pl
}

Received: 2016.08 .01 Accepted: 2016.09 .26 Published: 2016.11.01

\begin{abstract}
This paper reports the results of tillage experiments that were set up to investigate the intensity of net soil displacement and the associated tillage erosivity for mouldboard tillage carried out in direction parallel to the contour lines (contour tillage). Tillage was performed with typical set of cultivation for an average farm on soil developed from loess located on a slope with 7.5 to $13.5 \%$ decrease. Aluminium cubes of $15 \mathrm{~cm}$ edge-length were used as tracers. The studies showed that average translocation of soil along the slope (perpendicular to tillage direction) was $0,35 \mathrm{~m}$ and $0,28 \mathrm{~m}$ respectively for tillage with downslope and upslope direction of soil overturning. It means that each year about $2,89 \mathrm{Mg}$ per hectare of soil is net displaced in downslope direction per plough operation. The studies indicated that contour moldboard tillage is also an important factor in relief and soil transformation of eroded areas.
\end{abstract}

Keywords: tillage erosion, mouldboard plowing, contour tillage

\section{INTRODUCTION}

In the agricultural sciences, already in 1930 it was accepted that soil erosion is understood primarily as a process of destruction of soil by water and wind. In the course of the study different destructive natural forces affecting the soil were considered (gravity, glaciers, snow, temperature) [Józefaciuk and Józefaciuk 1995]. Many of them have marginal importance from the viewpoint of the economic impact on a global scale. A common process of degradation (with very significant impacts) that for several decades was on the margins of research of erosion is tillage erosion. This term describes the displacement of soil under the effect of agricultural implements [Rejman and Paluszek 2005]

First trials of experimental tillage erosion research (caused by moldboard plowing) were began in the 1940's. A supporter of this trend of research in Poland was Professor Bac [1950]. Researches were already broken at the beginning of the sixties. Investigations conducted during this period in Poland, mainly focused on selection of moldboard for plowing in mountainous areas and determining movement of soil due to different direction of cultivation. Investigations were conducted one-bladed horse-drawn and tractor-drawn ploughs, using different methodology [Bac 1950; Czyżyk 1955, Martini 1955]. After discontinuation of direct studies, in Polish literature (up to 21 st century), only a mention or very approximate estimations of intensity of tillage erosion were appeared, resulting from tests of soil cover or changes in the high boundary strips [Mazur 1972; Józefaciuk and Józefaciuk 1995; Twardy 1998].

After several decades of pause the problem of soil movement by tillage (mainly moldboard plowing) has gained widespread attention in foreign literature in the 1990's again [Stach 2006]. The methodical regards had important role in the quick progress of investigations over tillage erosion. Within a few years, many methods enabling comparatively simple and cheap way for management of controlled field experiments were 
worked. These include using of various types of markers placed in the soil before plowing and recovered after carrying out [Lobb et al. 2001]. For this purpose radioactive marking of soils with cesium 134 was also used [Quine et al. 1999].

For the first time, based on field experiments correlation between the size of tillage erosion and decrease of slope was found [Lindstrom et al. 1990]. In a short time were created a series of research work carried out in different agroenvironmental conditions, using different materials as indicators to measure the distance of soil displacement. These studies indicated that the amount of soil displaced under the influence of tillage tools (including mouldboard ploughs, deep-tillers, disc harrows, light spring-toothharrows, seeders and hand tools) in some cases is at least equal to water erosion or repeatedly surpasses it [Lindstrom et al. 1992; Govers et al. 1994; Lobb et al. 1999; Van Oost et al. 2005; Zhang et al. 2004]. Similar conclusions have also been confirmed in the Polish study [Rejman and Paluszek 2005; Rejman 2006].

Moreover, Van Muysen et al. [1999] clearly shows that an additional relevant factor in determining of tillage erosion was the initial soil conditions. It was found that tillage erosion was about 3.6 times more important when tillage is done on a freshly tilled (loose) soil than on a soil under a few years grass followed. Whilst examining the impact of crop cultivation parameters such as depth, speed and direction on the size of the erosion Van Muysen et al. [2002] were demonstrated that the along slope tillage is about $22 \%$ more erosive than the contour tillage carried out with a similar depth and speed. In Poland, the contributory study of quantitative assessment of tillage erosion, after almost 50 years break, was conducted by Rejman and Paluszek [2005] and Rejman [2006]. Experiments were conducted for up-downslope direction, on sections of constant slope inclination. It was found that tillage is an important factor that modifies the sculpture of surface and soil in eroded areas.

The constant progress in agriculture, comprising initially to replace the horse by tractors and now the use of machines with ever-increasing power and performance means that the speed of cultivation treatments increases. The amount of energy supplied to the system which is the soil increases too. By this soil can be displaced to the greater distance. At the same time progress in equipment of farms with modern ma- chinery does not always mean equip a reversible ploughs, which always allows overturning of soil only in one (the same) direction. Still mouldboard ploughs are used forcing to perform furrows plowing. It means that for there and back tillage the ridge is overturned in different directions.

For the agronomic recommendations of eroded areas a common of the principle of limiting the erosion is to perform cultivation treatments across the slope. For most tools used for cultivation, crossing there and back made no difference in the movement of soil in relation to the slope. However specific in this respect is plough. Because is not always possible to use the reversible ploughs (to put the ridges up the slope) for contour plowing are used mouldboard ploughs. It means that even in case of antierosion cultivation half of the field is plowed with the overturning ridges down the slope. This causes additional (next to water erosion) displacement of soil down the slope.

The aim of the study is to determine the size of displacement of soil (tillage erosion) on the loess slope due to mouldboard plowing performed crosswise to decrease using a typical set of cultivation for an average farm.

\section{MATERIAL AND METHODS}

The study was conducted on lessive soil developed from loess in West Roztocze (in the Por river basin) in the municipality of Turobin. This area due to the typical upland areas sculpture is threatened with erosion. Before tillage a detailed topographical survey of the area was made using an automatic theodolite. Sowing plow to a depth of less than $20 \mathrm{~cm}$ (for the buckwheat cultivation) was carried out across the slope with an inclination of about $7 \%$ to $13 \%$ (30.04.2013). Treatments were conducted using 3-bladed plough U023/1 with a working width $0.8 \mathrm{~m}$ pulled by a $38 \mathrm{~kW}$ tractor. Plowing speed in both directions was 1.5 $\mathrm{m} \cdot \mathrm{s}^{-1}$ (measurement performed in real time using a GPS). Before and after the cultivation samples of the soil were taken to determine bulk density and soil moisture. Before plowing the soil bulk density was $1480 \mathrm{~kg} \cdot \mathrm{m}^{-3}$, after plowing 1120 $\mathrm{kg} \cdot \mathrm{m}^{-3}$. Soil moisture was 18 and $17.8 \%$.

Measurement of tillage erosion was carried out according to the methodology taken from work carried out at the University of Leuven 
(Belgium) [Govers et al. 1994; Van Muysen et al. 1999; 2002]. This method involves the assessment of soil translocation on the basis of changes in the position of introduced into the soil numbered aluminum cubes with an edgelenght of $15 \mathrm{~mm}$ (as tracers). Tracers were placed at depths of $0,5,10,15$ and $20 \mathrm{~cm}$ in a drilled with a $0.10 \mathrm{~m}$ spacing holes. Exact position of each of them was registered by using an automatic theodolite. Tracers were inserted at 6 strip plots of ca. $1 \mathrm{~m}$ wide ( 3 strip plots for overturning soil upslope and 3 strip plots for overturning soil downslope). A total of 300 tracers were inserted -50 in each strip. As can be seen in Figure 1, this procedure resulted in a good vertical distribution of the tracers throughout the plough layer. Immediately after cultivation, the soil on the area of potential movement of tracers was carefully revealed and the exact position of each of the found re-registered. A recovery rate of tracers in excess of $90 \%$ for all strips was obtained. From the data, individual horizontal displacement distances of the tracers as well as the mean displacement distance perpendicular to the direction of tillage $\left(\mathrm{d}_{\mathrm{lat}}\right)$ and in the direction of tillage $\left(\mathrm{d}_{\text {long }}\right)$ were calculated for each strip (Table 1). In these calculations, only those tracers that were effectively displaced were used. Tracers that were situated below the plough layer, were excluded from the analysis. No corrections were made for lost tracers. Needed for further analysis average slope gradients perpendicular to the direction of tillage $\left(\mathrm{S}_{\text {lat }}\right)$ as well as in the direction of tillage $\left(\mathrm{S}_{\text {long }}\right)$ were calculated based on the detailed digital elevation model. Using

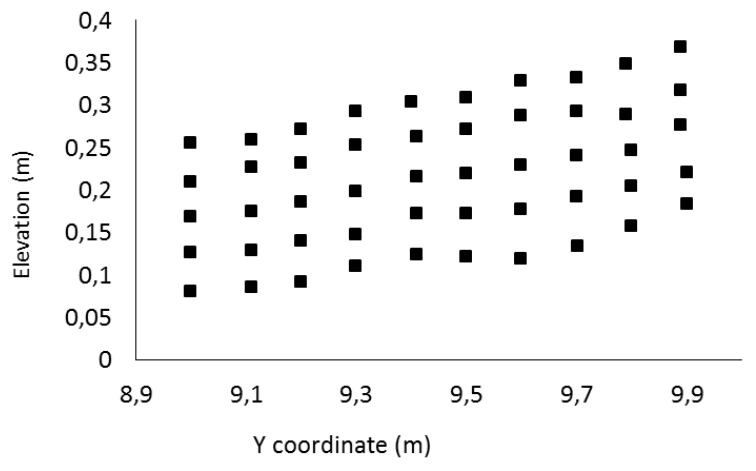

Figure 1. Vertical cross-section of a tracer strip (- aluminum tracer)

the convention proposed by Lindstrom at al. [1992] and Van Muysen at al. [2002] negative values were taken for $S_{\text {lat }}$ for tillage with overturning of soil in the downslope direction and positive for overturning in the upslope direction. Similarly $\mathrm{S}_{\text {long }}$ was taken negative for tillage conducted with the decline and positive for tillage conducted opposite the decline.

\section{RESULTS AND DISCUSION}

For the plowing performed across the slope, the most important in aspect of soil degradation is displacement perpendicular to the direction of cultivation - along the slope $\left(\mathrm{d}_{\text {lat }}\right)$. Distances of displacement of soil for tillage with overturning of ridges in the downslope direction were greater than overturning in the upslope direction (Table 1, Figure 2, Figure 4a). These distances are characterized by the large variability

Table 1. Summary of tillage translocation experiment data

\begin{tabular}{|c|c|c|c|c|c|c|c|c|c|c|c|}
\hline \multirow{3}{*}{\multicolumn{2}{|c|}{ Treatment }} & \multicolumn{2}{|c|}{$\begin{array}{c}\text { Slope gradient } \\
\mathrm{m} \cdot \mathrm{m}^{-1}\end{array}$} & \multirow{3}{*}{$\begin{array}{l}\text { Tillage } \\
\text { depth } \\
{[\mathrm{m}]}\end{array}$} & \multirow{3}{*}{$\begin{array}{l}\text { Tillage } \\
\text { speed } \\
{\left[\mathrm{m} \cdot \mathrm{s}^{-1}\right]}\end{array}$} & \multirow{2}{*}{\multicolumn{3}{|c|}{$\begin{array}{c}\text { Displacement of tracers across } \\
\text { tillage direction }\end{array}$}} & \multirow{2}{*}{\multicolumn{3}{|c|}{$\begin{array}{l}\text { Displacement of tracers } \\
\text { in tillage direction }\end{array}$}} \\
\hline & & \multirow{2}{*}{$\begin{array}{c}\text { Across } \\
\text { tillage } \\
\text { direction } \\
\mathrm{S}_{\text {lat }} \\
\end{array}$} & \multirow[b]{2}{*}{$\begin{array}{c}\text { In tillage } \\
\text { direction } \\
S_{\text {long }}\end{array}$} & & & & & & & & \\
\hline & & & & & & $\begin{array}{c}\text { Average } \\
{[\mathrm{m}]}\end{array}$ & $\begin{array}{c}\text { Standard } \\
\text { deviation } \\
{[\mathrm{m}]}\end{array}$ & $\begin{array}{c}\text { Variation } \\
\text { coefficient } \\
{[\%]}\end{array}$ & $\begin{array}{c}\text { Average } \\
{[\mathrm{m}]}\end{array}$ & $\begin{array}{c}\text { Standard } \\
\text { deviation } \\
{[\mathrm{m}]}\end{array}$ & $\begin{array}{c}\text { Variation } \\
\text { coefficient } \\
{[\%]}\end{array}$ \\
\hline $\begin{array}{l}\text { Soil overturn- } \\
\text { ing in the } \\
\text { downslope } \\
\text { direction }\end{array}$ & $\begin{array}{l}1 \\
2 \\
3\end{array}$ & $\begin{array}{l}-0,135 \\
-0,101 \\
-0,075\end{array}$ & $\begin{array}{l}-0,023 \\
-0,020 \\
-0,019\end{array}$ & $\begin{array}{l}0,14 \\
0,17 \\
0,17\end{array}$ & $\begin{array}{l}1,5 \\
1,5 \\
1,5\end{array}$ & $\begin{array}{l}0,31 \\
0,36 \\
0,39\end{array}$ & $\begin{array}{l}0,17 \\
0,19 \\
0,22\end{array}$ & $\begin{array}{l}52 \\
65 \\
57\end{array}$ & $\begin{array}{l}0,36 \\
0,34 \\
0,31\end{array}$ & $\begin{array}{l}0,23 \\
0,18 \\
0,18\end{array}$ & $\begin{array}{l}62 \\
46 \\
57\end{array}$ \\
\hline \multicolumn{2}{|c|}{ Average } & & & 0,16 & 1,5 & 0,35 & & & 0,34 & & \\
\hline $\begin{array}{l}\text { Soil overturn- } \\
\text { ing in the } \\
\text { upslope direc- } \\
\text { tion }\end{array}$ & $\begin{array}{l}1 \\
2 \\
3 \\
\end{array}$ & \multirow[t]{2}{*}{$\begin{array}{l}0,095 \\
0,084 \\
0,074\end{array}$} & \multirow[t]{2}{*}{$\begin{array}{l}0,020 \\
0,017 \\
0,013\end{array}$} & $\begin{array}{l}0,16 \\
0,16 \\
0,14\end{array}$ & $\begin{array}{l}1,5 \\
1,5 \\
1,5\end{array}$ & $\begin{array}{l}0,29 \\
0,25 \\
0,31\end{array}$ & $\begin{array}{l}0,16 \\
0,20 \\
0,20\end{array}$ & $\begin{array}{l}66 \\
99 \\
80\end{array}$ & $\begin{array}{l}0,29 \\
0,28 \\
0,36\end{array}$ & $\begin{array}{l}0,10 \\
0,24 \\
0,20\end{array}$ & $\begin{array}{l}42 \\
75 \\
48\end{array}$ \\
\hline \multicolumn{2}{|c|}{ Average } & & & 0,15 & 1,5 & 0,28 & & & 0,31 & & \\
\hline
\end{tabular}



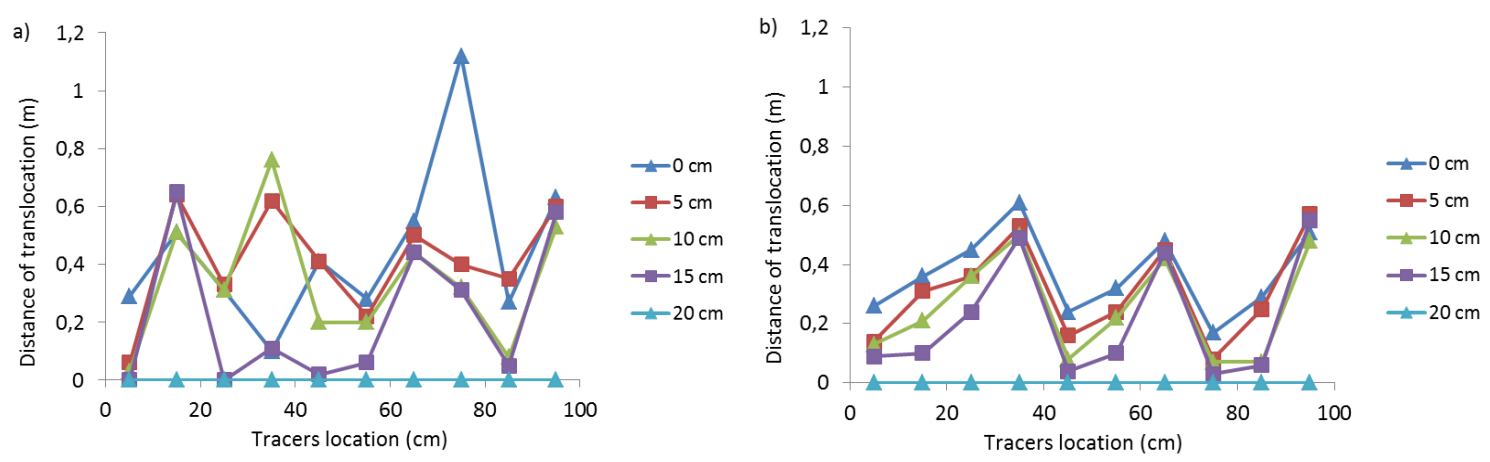

Figure 2. Translocation of tracers placed at various depth across tillage direction: a) soil overturning in the downslope direction; b) soil overturning in the upslope direction
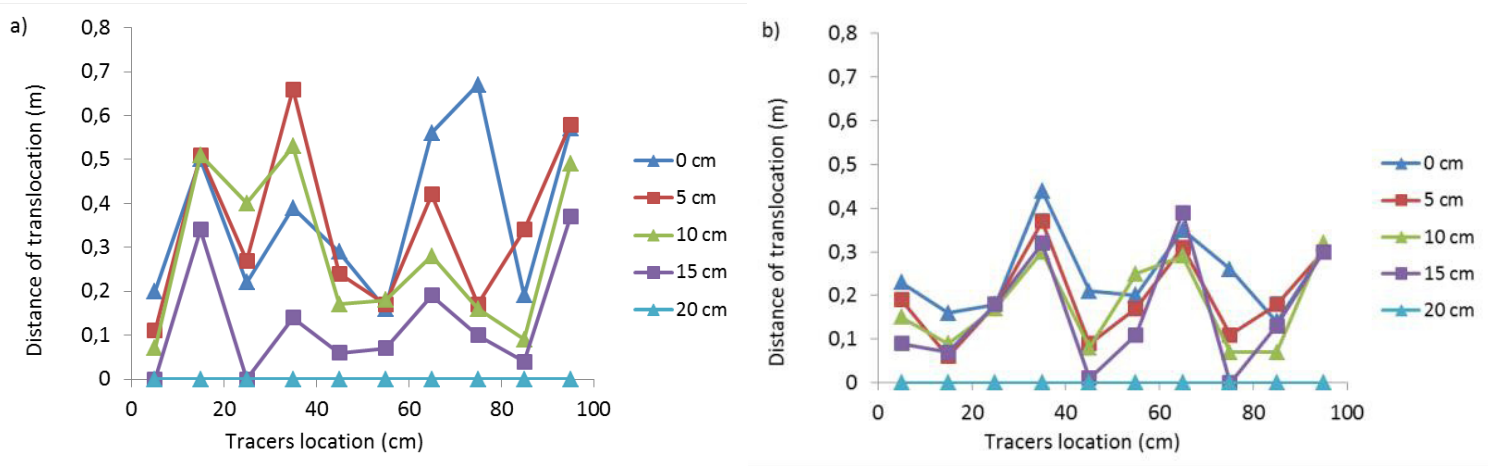

Figure 3. Translocation of tracers placed at various depth in the tillage direction: a) soil overturning in the downslope direction; b) soil overturning in the upslope direction

a)

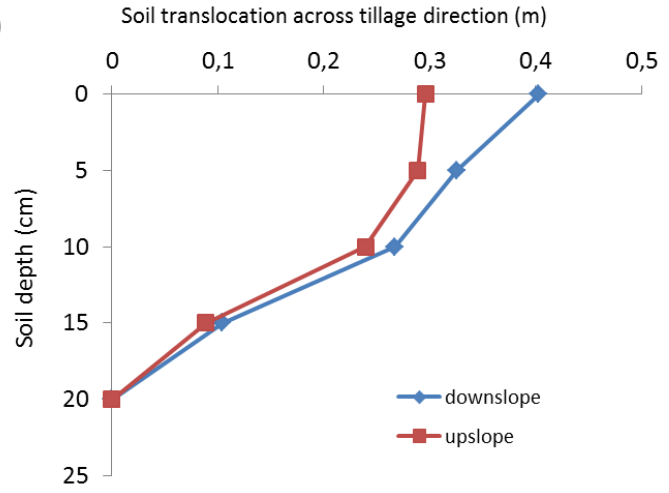

b)

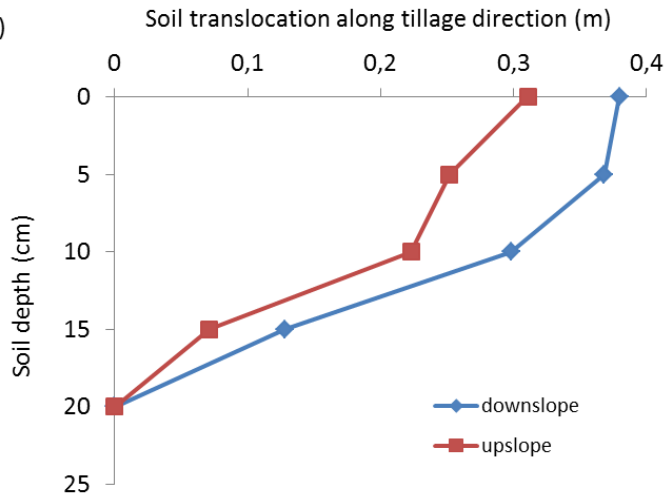

Figure 4. Profile of soil translocation: a) across tillage direction; b) along tillage direction

with variation coefficient in the range of 52 to $99 \%$. A similar spread of variability also indicated Van Muysen et al [1999] and Rejman and Paluszek [2005] study. They point out that for this state is mainly responsible the construction of plough. The maximum displacement distance reached respectively $1.12 \mathrm{~m}$ for soil overturning in the downslope direction and $0.69 \mathrm{~m}$ for soil overturning in the upslope direction. Generally markers primary located closer to the surface were moved the greater distances. Similar conclusions were reached in Rejman and Paluszek [2005] studies. Mean displasement distance of the soil across to the direction of plowing amounted to $0.35 \mathrm{~m}$ for downslope overturning and $0.28 \mathrm{~m}$ for upslope overturning, and were primarily affected by the slope gradient.

The relationship between soil translocation data and slope gradient is often analyzed by plotting the mean tracer displacement distance versus 
the slope gradient and calculating linear regression statistics for this relationship. An estimate of the tillage transport coefficient $k$ can then be calculated as [Van Muysen et al. 2002]:

$k=-0,5 D \cdot \rho_{\mathrm{b}} \cdot B$

where: $k$ is the tillage transport coefficient $\left(\mathrm{kg} \cdot \mathrm{m}^{-1}\right.$ per tillage operation),

$D$ is the tillage depth (m);

$B$ is the slope of the regression equation of the relationship between soil displacement and slope gradient, obtained from up- and downslope tillage experiments, $\rho_{b}$ is the bulk density of the soil $\left(\mathrm{kg} \cdot \mathrm{m}^{-3}\right)$.

The relationship between mean tracer displacement distance and slope gradient for each of the tillage treatments is presented in Figure 5.

Coefficient $k$ finally allows to relate the net unit soil transport rate (tillage erosion) $Q_{\mathrm{s}, \text { net }}$ $\left(\mathrm{Mg} \cdot \mathrm{ha}^{-1}\right.$ per tillage operation) due to a specific tillage operation to the slope gradient $S$ [Van Muysen et al. 2002].

$Q_{\text {s,net }}=k \cdot S$

The experimental results show that the mean displacement of soil after both tillage operation increases with decreasing slope gradient (Figure 5a). These relationships can be described by linear regression equations:

$\mathrm{d}_{\text {lat }}=0,31-0,31 \mathrm{~S}_{\text {lat }}\left(\mathrm{n}=6, \mathrm{r}^{2}=0,96, \mathrm{p}<0,001\right)$

where: $d_{\text {lat }}$ is the mean horizontal tracer displacement distance across the tillage direction (m) and $\mathrm{S}_{\text {lat }}$ the slope gradient $\left(\mathrm{m} \cdot \mathrm{m}^{-1}\right)$.

Reduction of average displacement distance of the soil concurrently with the increase of slope gradient for upslope overturning of ridges is obvious and due to the force of grav- ity. Soil is harder moved uphill. Moreover part of the soil (the ridge) rolls down the slope, thereby reducing displacement distance. This is confirmed by the study Van Muysen et al. [2002]. However, in the case of downslope overturning the soil, it would seem that with the increase of the slope gradient it will grow also displacement of distance of the soil. The results of this study indicate that this relationship is opposite. It seems that this is caused by factors related to the parameters of the tillage. At such shallow plowing $(0.16 \mathrm{~m}-$ Table 1$)$ and low speed operation $\left(1.5 \mathrm{~m} \cdot \mathrm{s}^{-1}\right)$ soil can slide from the plow immediately after cutting by the blade of the plow. Therefore, soil does not get the moldboard, which could cause further displacement distance. In this arrangement the soil slipping from the plough moldboard is further compounded by the tilt of the plough blade corresponding to a slope gradient.

The experimental results allow to calculate the tillage transport coefficient $k$. For contour tillage with downslope and upslope overturning of the soil $\mathrm{k}=32.1 \mathrm{~kg} \cdot \mathrm{m}^{-1}$ per tillage operation. The average net displacement distance of the soil down the slope was $0.07 \mathrm{~m}$. Assuming the average inclination of field $\left(0.09 \mathrm{~m} \cdot \mathrm{m}^{-1}\right)$ the average size of tillage erosion under the test conditions amounts to $Q_{\text {s.net }}=2.89 \mathrm{Mg}$ of soil per hectare. According to Van Muysen et al. [2002] it is important that the estimation of the tillage transport coefficient using Eq. 1 and tillage erosion using Eq. 2 it will only be valid if tillage at a given location occurs on average with the same frequency in the up- and downslope direction. If, for some reason, part of a field is always tilled in the upslope direction, there will be none or very little tillage erosion in this area, except near field borders,
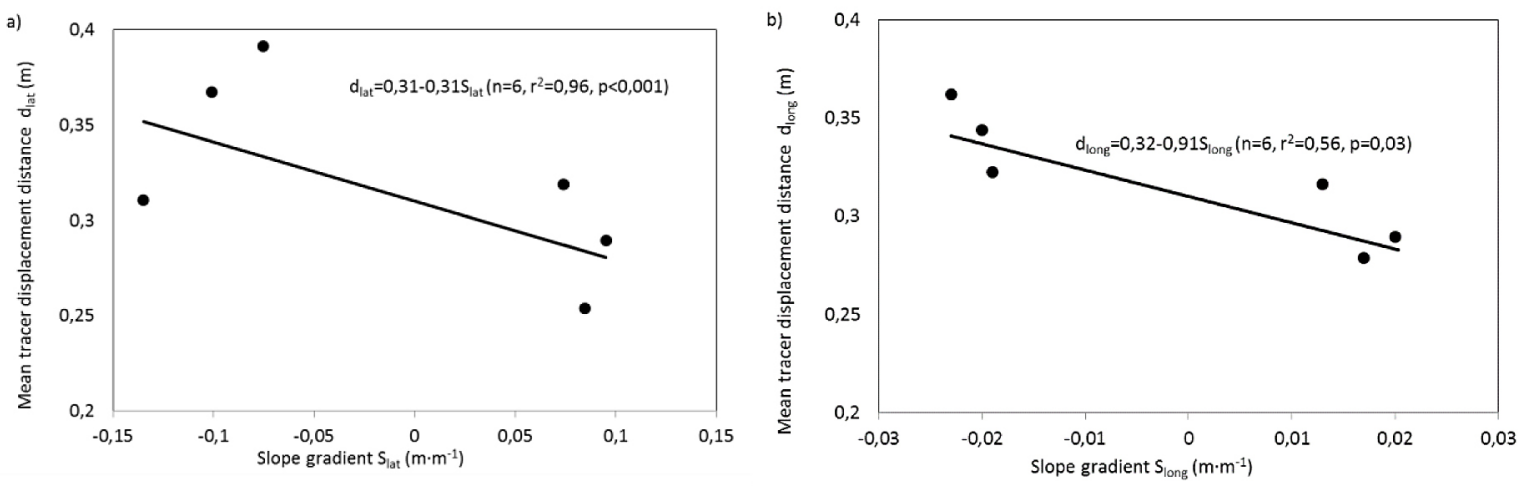

Figure 5. Mean displacement vs. slope gradient for mouldboard tillage: (a) displacement perpendicular to the tillage direction $\left(\mathrm{d}_{\text {lat }}\right.$ vs. $\left.\mathrm{S}_{\text {lat }}\right)$; b) displacement in the direction of tillage $\left(d_{\text {long }}\right.$ vs. $\left.S_{\text {long }}\right)$ 
where erosion occurs at the downslope end of the field and deposition at the upslope end of the field. If tillage occurs always in the downslope direction, erosion rates will be double of those estimated when Eq. 1 is used.

For comparison, the results of Rejman and Paluszek [2005] show that for deep plowing performed along the slope at a similar slope gradient and similar soil to tested in this work, the resulting net tillage erosion was 3.4 $\mathrm{Mg} \cdot \mathrm{ha}^{-1}$. Therefore, contour cultivation in the case of the use of mouldboard plough, can cause a little less tillage erosion than the cultivation along the slope.

Unlike analyzed above the displacement of soil along the contour tillage seems to be less important. Nevertheless, this displacement can also take part in the modification of the surface of the sculpture and soil of eroded areas. $\mathrm{D}_{\text {long }}$ mean values are similar to $d_{\text {lat }}$ values for tillage with overturning of soil in the downslope direction and slightly higher than values for overturning in the upslope direction (Figure 3). Displacement distance along the tillage direction characterized by lower variability than across the tillage direction (coefficients of variation in the range of 42 to $75 \%)$ - Table 1.

The maximum distance of displacement of tracers along tillage direction by the tillage overturning the ridges upslope reaching up to 0.84 $\mathrm{m}$, with an average of 0.28 to $0.36 \mathrm{~m}$. For tillage overturning the ridges downslope the maximum distance of displacement of tracers along tillage direction reaching up to $0.67 \mathrm{~m}$, with an average of 0.31 to $0.36 \mathrm{~m}$. For the whole profile mediumdistance of tracers translocation along tillage were respectively 0.31 and $0.34 \mathrm{~m}$. It means that net soil displacement equal $0.03 \mathrm{~m}$ per tillage operation. Slope gradient of the considered displacement direction were small and medium amounted $\mathrm{S}_{\text {long }}=0.018 \mathrm{~m} \cdot \mathrm{m}^{-1}$.

These relationships for this results can be described by linear regression equations (Figure $5 \mathrm{~b}$ ):

$\mathrm{d}_{\text {long }}=0,32-0,91 \mathrm{~S}_{\text {long }}\left(\mathrm{n}=6, \mathrm{r}^{2}=0,56, \mathrm{p}=0,03\right)$

Tillage transport coefficient along tillage direction for contour plowing equals $\mathrm{k}=104$ $\mathrm{kg} \cdot \mathrm{m}^{-1}$ per tillage operation. Assuming average decline in the direction of displacement $\left(\mathrm{S}_{\text {long }}=0.018 \mathrm{~m} \cdot \mathrm{m}^{-1}\right)$, the average size of tillage erosion under the test conditions amounts to $\mathrm{Q}_{\mathrm{s} \text {, net }}=1.8 \mathrm{Mg}$ of soil per hectare and was about $60 \%$ lower than in $\mathrm{S}_{\text {lat }}$.

\section{CONCLUSIONS}

Assessed on the basis of conducted research, following conclusions can be formulated.

1 . Under the test conditions (average slope gradient $\mathrm{S}_{\text {lat }}=0,09 \mathrm{~m} \cdot \mathrm{m}^{-1}$, average depth of tillage $\mathrm{D}=0,155 \mathrm{~m}$, average speed $\mathrm{V}=1,5 \mathrm{~m} \cdot \mathrm{s}^{-1}$, bulk density of the soil $\rho_{\mathrm{b}}=1480 \mathrm{~kg} \cdot \mathrm{m}^{-3}$ ) average size of tillage erosion in downslope direction amounts to $Q_{\mathrm{s}, \mathrm{net}}=2.89 \mathrm{Mg}$ soil per hectare.

2. Common considered as anti-erosion cultivation across the slope, in the case of tillage performed by mouldboard plough causes net soil displacement down the slope, but it is smaller than in the case of mouldboard tillage on the same field along the slope.

3. The studies demonstrate that the contour mouldboard tillage is also an important albeit slow modifying factor the surface of the sculpture and the soil in eroded areas.

\section{REFERENCES}

1. Bac S. 1950. Effect of plough work on the movement of soil. Polish Annals of Agricultural Sciences. 54, 61-80. (In Polish)

2. Czyżyk W. 1955. Redepositioning of soil on slopes as a results of plowing. Polish Annals of Agricultural Sciences. 71, F-1, 73-88. (In Polish)

3. Govers G., Vandaele K., Desmet P., Poesen J., Bunte K. 1994. The role of tillage in soil redistribution on hillslopes. European Journal of Soil Science. $45,469-478$.

4. Józefaciuk A., Józefaciuk C. 1995. Erosion of agroecosystems. Nat. Insp. of Env. Prot. IUNG Pulawy. (In Polish)

5. Lindstrom M.J., Nelson W.W., Schumacher T.E., Lemme G.D. 1990. Soil movement by tillage as affected by slope. Soil and Tillage Res. 17, 255-264.

6. Lindstrom M.J., Nelson W.W., Schumacher T.E. 1992. Quantifying tillage erosion rater due to moldboard plowing. Soil and Tillage Res. 24, 243-255.

7. Lobb D.A., Kochanoski R.G., Miller M.H. 1999. Tillage translocation and tillage erosion in the complex upland landscapes of southwestern Ontario, Canada. Soil and Tillage Res. 51, 189-209.

8. Lobb D.A., Quine T.A., Govers G., Heckrath G.J. 2001. Comparison of methods used to calculate tillage translocation using plot-tracers. Journal of Soil and Water Conservation. 56, 321-328.

9. Martini Z. 1955. The arrangements for the theory of operation of agricultural implements. Polish An- 
nals of Agricultural Sciences. 71, F-1, 57-72. (In Polish)

10. Mazur Z. 1972. Changes of sculptures in the cultivated loess slopes in Elizówka. Annales UMCS, E, 27(10), 61-68. (In Polish)

11. Quine T.A., Walling D.E., Chakela Q.K., Mandiringana O.T., Zhang X. 1999. Rates and patterns of tillage and water erosion on terraces and contour strips: evidence from caesium-137 measurements. Catena. 36, 115-142.

12. Rejman J. 2006. Effect of water and tillage erosion on transformation of soils and loess slopes. Acta Agroph. 3. pp. 91. (In Polish)

13. Rejman J., Paluszek J. 2005. Evaluation of soil translocation due to deep mouldboard plow. Acta Agroph. 5(1), 129-135. (In Polish)

14. Stach A. 2006. Agricultural soil erosion due to tillage and crop harvesting. Annals AR in Poznań. CCCLXXV, 163-179. (In Polish)

15. Twardy J. 1998. The results of measurements of the rate of agrotechnical denudation in the Lodz area. Advances of Agricultural Sciences Problem Issues. 460, 599-609. (In Polisch)

16. Van Muysen W., Govers G., Bergkamp G., Roxo M., Poesen J. 1999. Measurement and modelling of the effects of initial soil conditions and slope gradient on soil translocation by tillage. Soil and Tillage Res. 51, 303-316.

17. Van Muysen W., Govers G., Van Oost K. 2002. Identification of important factors in the process of tillage erosion: the case of mouldboard tillage. Soil and Tillage Res. 65, 77-93.

18. Van Oost K., Van Muysen W., Govers G., Deckers J., Quine T.A. 2005. From water to tillage erosion dominated landform evolution. Geomorphology 72, 193-203

19. Zhang J.H., Lobb D.A., Li Y., Liu G.C. 2004. Assessment of tillage translocation and tillage erosion by hoeing on the steep land in hilly areas of Sichuan, China. Soil and Tillage Res. 75, 99-107.

Pracę dofinansowano ze środków Wojewódzkiego Funduszu Ochrony Środowiska i Gospodarki Wodnej w Lublinie. 